\title{
Characterization of a porin channel in the endosymbiont of the trypanosomatid protozoan Crithidia deanei
}

Correspondence

Ronaldo Mohana-Borges

mohana@biof.ufr.br

Maria Cristina Machado Motta

motta@biof.ufrj.br
Received 22 February 2011

Revised 28 June 2011

Accepted 12 July 2011 lamara da Silva Andrade, 1,2,3 João Lídio Vianez-Júnior, ${ }^{4}$ Carolina Lage Goulart, 3,5,6 Fabrice Homblé, ${ }^{6}$ Jean-Marie Ruysschaert, ${ }^{6}$ Wanda Maria Almeida von Krüger, ${ }^{3,5}$ Paulo Mascarello Bisch, ${ }^{3,4,5}$ Wanderley de Souza, 1,3,7 Ronaldo Mohana-Borges 2,3 and Maria Cristina Machado Motta ${ }^{1,3}$

${ }^{1}$ Laboratório de Ultraestrutura Celular Hertha Meyer, Instituto de Biofísica Carlos Chagas Filho, Universidade Federal do Rio de Janeiro, 21941-590 Rio de Janeiro, Brazil

${ }^{2}$ Laboratório de Genômica Estrutural, Instituto de Biofísica Carlos Chagas Filho, Universidade Federal do Rio de Janeiro, 21941-590 Rio de Janeiro, Brazil

${ }^{3}$ Instituto Nacional de Ciência e Tecnologia em Bioimagens e Biologia Estrutural, Centro de Ciências da Saúde, Universidade Federal do Rio de Janeiro, Cidade Universitária, Ilha do Fundão, 21941-590 Rio de Janeiro, Brazil

${ }^{4}$ Laboratório de Física Biológica, Instituto de Biofísica Carlos Chagas Filho, Universidade Federal do Rio de Janeiro, 21941-590 Rio de Janeiro, Brazil

${ }^{5}$ Unidade Multidisciplinar de Genômica, Instituto de Biofísica Carlos Chagas Filho, Universidade Federal do Rio de Janeiro, 21941-590 Rio de Janeiro, Brazil

${ }^{6}$ Laboratoire de Structure et Fonction des Membranes Biologiques (SFMB), Université Libre de Bruxelles, Campus Plaine (CP 206/2), B-1050 Bruxelles, Belgium

${ }^{7}$ Instituto Nacional de Metrologia, Normalização e Qualidade Industrial, Inmetro, Rio de Janeiro, Brazil

Crithidia deanei is a trypanosomatid protozoan that harbours a symbiotic bacterium. The partners maintain a mutualistic relationship, thus constituting an excellent model for studying metabolic exchanges between the host and the symbiont, the origin of organelles and cellular evolution. According to molecular analysis, symbionts of different trypanosomatid species share high identity and descend from a common ancestor, a $\beta$-proteobacterium of the genus Bordetella. The endosymbiont is surrounded by two membranes, like Gram-negative bacteria, but its envelope presents special features, since phosphatidylcholine is a major membrane component and the peptidoglycan layer is highly reduced, as described in other obligate intracellular bacteria. Like the process that generated mitochondria and plastids, the endosymbiosis in trypanosomatids depends on pathways that facilitate the intensive metabolic exchanges between the bacterium and the host protozoan. A search of the annotated symbiont genome database identified one sequence with identity to porin-encoding genes of the genus Bordetella. Considering that the symbiont outer membrane has a great accessibility to cytoplasm host factors, it was important to characterize this single porin-like protein using biochemical, molecular, computational and ultrastructural approaches. Antiserum against the recombinant porin-like molecule revealed that it is mainly located in the symbiont envelope. Secondary structure analysis and comparative modelling predicted the protein $3 \mathrm{D}$ structure as an 18-domain $\beta$-barrel, which is consistent with porin channels. Electrophysiological measurements showed that the porin displays a

Abbreviations: ASB-14, amidosulfobetaine-14; CD, circular dichroism; IM, inner membrane; OM, outer membrane; RMSD, root mean square deviation; VDAC, voltage-dependent anion-selective channel.

The GenBank/EMBL/DDBJ accession number for the porin sequence of the Crithidia deanei endosymbiont is HM480845.

Three supplementary figures, showing a sequence alignment of the endosymbiont protein and Delftia acidovorans Omp32, a 3D structure model of the endosymbiont $C$. deanei porin, and nucleotide and amino acid sequences of the $C$. deanei endosymbiont porin, are available with the online version of this paper. 
slight preference for cations over anions. Taken together, the data presented herein suggest that the C. deanei endosymbiont porin is phylogenetically and structurally similar to those described in Gram-negative bacteria, representing a diffusion channel that might contribute to the exchange of nutrients and metabolic precursors between the symbiont and its host cell.

\section{INTRODUCTION}

Membranes of cells and organelles delimit the internal and external environments and mediate essential biological functions, such as transport of nutrients and waste products, transmission of external information, energy transduction and cellular growth. The membranes contain receptors, translocases and channel-forming proteins that are involved in such cellular activities. In Gram-negative bacteria, the envelope is composed of two protein-lipid bilayers, usually referred to as the inner membrane (IM) and outer membrane $(\mathrm{OM})$. In contrast to the IM, the OM is asymmetrical with respect to lipid composition. The inner leaflet is composed of phospholipids and the outer leaflet contains mainly lipopolysaccharides (LPS), explaining the unusually slow influx of lipophilic solutes through this membrane. Regarding protein content, the IM presents permeases and transmembrane transporters bearing hydrophobic $\alpha$-helices, whereas the OM contains a large number of $\beta$-barrel translocases and pore-forming proteins. The last two components function as porins that mediate the uptake and efflux of a wide range of nutrients across the $\mathrm{OM}$, and which are defined as water-filled channels through which molecules of up to $600 \mathrm{Da}$ may diffuse (Nikaido \& Rosenberg, 1981).

Porins are composed of transmembrane amphipathic $\beta$ strands connected by hydrophilic loops that extend into the intermembrane space or out to the extracellular environment. These loops can function as regulatory or ion-selective regions of the channels (Nikaido, 2003). Gram-negative bacteria present three different classes of porins (Klebba \& Newton, 1998): (i) classical or general diffusion porins, which do not bind solutes and are exemplified by OmpF, OmpC and PhoE; (ii) solute-specific porins such as LamB, which facilitate the influx of a wide variety of carbohydrates when they are in low concentration in the environment; and (iii) ligand-gated porins, which bind a substrate and use energy to induce conformational changes in the channel to transport molecules. It is worth mentioning that some authors employ the word 'porin' exclusively to refer to non-specific channels (Nikaido, 2003).

Bacterial endosymbionts are the origin of mitochondria and chloroplasts via processes dependent on the acquisition and remodelling of the symbiont import and transport machineries. This evolutionary modification is supported by sequence homologies and functional analysis of $\beta$-barrel OM proteins, such as the protein import translocase complexes TOM in mitochondria and TOC in chloroplasts (Dolezal et al., 2006; Duy et al., 2007; Hewitt et al., 2011).
The mitochondrial porins also include a voltage-dependent anion-selective channel (VDAC), the most abundant protein of the mitochondrial $\mathrm{OM}$, which constitutes the main channel to transport metabolites and substrates (Colombini, 2004; Lemasters \& Holmuhamedov, 2006). Pore-forming proteins exhibiting $\beta$-barrel structures have also been characterized in chloroplasts; nonetheless, differences in their substrate specificity and gating suggest distinct roles in metabolic processes (Bölter \& Soll, 2001).

Some trypanosomatid protozoa harbour an endosymbiont that is descended from a $\beta$-proteobacterium of the genus Bordetella (Du et al., 1994). The partners have co-evolved in a mutualistic relationship characterized by intense metabolic exchanges. The endosymbiont contains enzymes and metabolic precursors that complete essential biosynthetic pathways of the host protozoan, such as the urea cycle and the production of haemin and polyamine (Camargo \& Freymuller, 1977; Frossard et al., 2006; Salzman et al., 1985). Conversely, the endosymbiont obtains some of the energy-containing molecules that it requires from host glycosomes, organelles in which most of the glycolytic pathway takes place (Motta et al., 1997b). Like Gram-negative bacteria, the symbiont is enclosed by two membrane units; however, the peptidoglycan layer is reduced and the septum is absent during cellular division (Motta et al., 1997a). Biochemical analysis has revealed that the symbiont envelope lacks sterols and contains cardiolipin and phosphatidylcholine as the major phospholipids (Palmié-Peixoto et al., 2006). Cardiolipin is a typical component of bacterial membranes; phosphatidylcholine, on the other hand, is mainly present in prokaryotes that maintain a close relationship with eukaryotic cells as parasites or symbionts (López-Lara \& Geiger, 2001).

There is scanty information about the protein composition of the endosymbiont envelope. Freeze-fracture electronmicroscopy analysis has revealed that the number of transmembrane proteins in its $\mathrm{OM}$ is similar to that described for Gram-negative bacteria (Motta et al., 1991; Soares et al., 1987). In order to get more information about the kind of metabolites and molecules exchanged between the symbiotic bacterium and the host trypanosomatid, it is essential to identify membrane proteins involved in transport across the symbiont envelope. In the present work, we have studied an OM protein of the trypanosomatid Crithidia deanei endosymbiont and confirmed its subcellular localization by biochemical, molecular, computational and ultrastructural approaches. Taken together, our results suggest that this OM protein is a porin, phylogenetically related to those described in Gramnegative bacteria, and constitutes a weak cation-selective 
channel with the ability to function as a diffusion pore across the symbiont envelope.

\section{METHODS}

Sequence homology search, and molecular and functional characterization. Sequence similarity searches were performed against the Swiss-Prot, Protein Data Bank (PDB) and NonRedundant (nr) protein databases of the National Center for Biotechnology Information (NCBI) (http://www.ncbi.nlm.nih.gov) using BLASTP (Altschul et al., 1990) and sequence alignments were produced using the PROMALS program (Pei \& Grishin, 2007). Secondary structures were predicted by using PSIPRED (Jones, 1999). Signal peptide prediction was conducted using SignalP 3.0 (Bendtsen et al., 2004). The COG (Tatusov et al., 2001) and Pfam (Finn et al., 2008) databases were used to search for conserved domains and protein families, respectively. Phylogenetic analyses were conducted using MEGA 4.0 (Kumar et al., 2008), and sequences were downloaded from the GenBank RefSeq (Pruitt et al., 2007) and Swiss-Prot databases. The phylogenetic tree was constructed using the neighbour-joining algorithm (Saitou \& Nei, 1987), and the distances were corrected using the maximum composite likelihood method (Tamura et al., 2004). The reliability of the tree was evaluated with 1000 bootstrap replicates (Efron et al., 1996).

Comparative modelling. A similarity search using BLASTP (Altschul et al., 1990) was performed against the PDB (Berman et al., 2000) to find suitable templates. Comparative protein models were built with Modeller 9v6 (Eswar et al., 2006), and their stereochemical quality was evaluated using Ramachandran plots generated by the PROCHECK program (Laskowski et al., 1993) and by Discrete Optimized Protein Energy (DOPE) (Eswar et al., 2006) scores generated by Modeller 9v6. The root mean square deviation (RMSD) of the backbone atoms $(\mathrm{C} \alpha)$ was calculated with Swiss-PdbViewer software (Guex \& Peitsch, 1997), and molecular structure inspections were made using PyMOL (PyMOL Molecular Graphics System, version 1.2r3pre, Schrödinger).

Cell growth. Symbiont-containing and aposymbiotic C. deanei strains were grown at $28{ }^{\circ} \mathrm{C}$ for $24 \mathrm{~h}$ in Warren's culture medium supplemented with $10 \%$ fetal calf serum (Warren, 1960).

Isolation of endosymbiont and mitochondrial fractions. A modified version of a described procedure was used (Alfieri \& Camargo, 1982). Briefly, cells were grown to exponential phase for $24 \mathrm{~h}$ in Warren's medium. Protozoa were centrifuged at $4000 \mathrm{~g}$ for $10 \mathrm{~min}$ and washed twice in PBS, pH 7.2. The pellet was resuspended in cold distilled water and left for $45 \mathrm{~min}$ on ice. Cells were then centrifuged at $4000 \mathrm{~g}$, resuspended in $12 \mathrm{ml} 20 \mathrm{mM}$ Tris/HCl, $0.25 \mathrm{M}$ sucrose, and sonicated using a W-380 ultrasonic disruptor (three $15 \mathrm{~s}$ pulses at $10 \%$ amplitude). The volume was adjusted to $20 \mathrm{ml}$ with $20 \mathrm{mM}$ Tris/ $\mathrm{HCl}, 0.25 \mathrm{M}$ sucrose, $2 \mathrm{mM} \mathrm{CaCl}_{2}, 10 \mathrm{mM} \mathrm{MgCl}_{2}$ and $25 \mathrm{mg}$ DNase type $\mathrm{I} \mathrm{ml}^{-1}$ (Sigma). Cells were incubated with this solution at $25{ }^{\circ} \mathrm{C}$ for $30 \mathrm{~min}$, and the volume was increased to $30 \mathrm{ml}$ with $20 \mathrm{mM}$ Tris/ $\mathrm{HCl}, 0.25 \mathrm{M}$ sucrose and $2 \mathrm{mM}$ EDTA. The homogenate was centrifuged at $5000 \mathrm{~g}$ for $20 \mathrm{~min}$, and the pellet obtained was resuspended in Tris/HCl/sucrose/EDTA buffer containing $0.5 \mathrm{mg} \mathrm{ml} \mathrm{m}^{-1}$ Pronase (protease type XIV from Streptomyces griseus, Sigma). The homogenate was then centrifuged at $4000 \mathrm{~g}$ for $20 \mathrm{~min}$. The pellet was resuspended in $10 \mathrm{ml}$ Tris/HCl/sucrose/EDTA buffer, and $2.5 \mathrm{ml}$ aliquots were layered over $2.5 \mathrm{ml} 0.5 \mathrm{M}$ sucrose. After centrifugation at $550 \mathrm{~g}$ for $10 \mathrm{~min}$, the upper layer was collected. The upper layer was centrifuged at $4000 \mathrm{~g}$ for $10 \mathrm{~min}$. The obtained supernatant was centrifuged at $10000 \mathrm{~g}$ for $10 \mathrm{~min}$, yielding a pellet which corresponds to the mitochondrial fraction, whereas the pellet obtained after the upper-layer centrifugation was resuspended in $6 \mathrm{ml}$
$20 \mathrm{mM}$ Tris/ $\mathrm{HCl}, 0.25 \mathrm{M}$ sucrose. The resuspended material was layered on the top of six tubes $(13 \mathrm{~mm} \times 51 \mathrm{~mm})$, each containing a two-step sucrose gradient consisting of $0.44 \mathrm{M}(2 \mathrm{ml})$ and $0.88 \mathrm{M}$ $(1 \mathrm{ml})$ sucrose. After centrifugation at $1740 \mathrm{~g}$ for $30 \mathrm{~min}$, the endosymbiont-containing pellet was collected.

Purification of endosymbiont DNA. The endosymbiont fraction was resuspended in $10 \mathrm{mM}$ Tris/ $\mathrm{HCl}, \mathrm{pH} 7.5$ and $1 \mathrm{mM}$ EDTA (TE buffer) and lysed in buffer containing $5 \mathrm{mM}$ EDTA, $10 \mathrm{mM} \mathrm{NaCl}$, $0.5 \%$ SDS and proteinase $\mathrm{K}\left(2 \mathrm{mg} \mathrm{ml}^{-1}\right)$ diluted in $10 \mathrm{mM} \mathrm{Tris} / \mathrm{HCl}$, $\mathrm{pH}$ 7.5. After incubation at $55^{\circ} \mathrm{C}$ for $1 \mathrm{~h}$, the endosymbiont DNA was extracted with phenol/chloroform $(\mathrm{v} / \mathrm{v})$ and precipitated with $3 \mathrm{M}$ sodium acetate, $\mathrm{pH} 6.0$, and $100 \%$ ethanol for $30 \mathrm{~min}$ in dry ice. After washing with $70 \%$ ethanol, the DNA pellet was dried and then resuspended in TE buffer. In order to remove nuclear and mitochondrial DNA, the endosymbiont DNA was further purified in a $\mathrm{CsCl}_{2}$ gradient: $80 \mu \mathrm{l}$ ethidium bromide $\left(10 \mathrm{mg} \mathrm{ml}^{-1}\right)$ was added to $2 \mathrm{ml} \mathrm{DNA} / \mathrm{CsCl}_{2}$ solution $\left(1 \mathrm{~g} \mathrm{CsCl}_{2} \mathrm{ml}^{-1}\right)$, followed by ultracentrifugation in a vertical rotor at $160000 \mathrm{~g}$ for $16 \mathrm{~h}$. The band containing the endosymbiont DNA was visualized with a UV lamp and collected via syringe through the side of the tube. The collected DNA was mixed with an equal volume of n-butyl alcohol, centrifuged for $2 \mathrm{~min}$ at $560 \mathrm{~g}$, and the supernatant, containing alcohol and ethidium bromide, was discarded. The endosymbiont DNA solution was dialysed against TE buffer solution containing $10 \mathrm{mM}$ Tris/HCl, $\mathrm{pH} 8.0$, and $1 \mathrm{mM}$ EDTA, and its concentration was measured spectrophotometrically. An aliquot of this DNA sample was analysed by electrophoresis in a $0.6 \%$ agarose gel to check its integrity.

Bacterial strains, vectors and growth conditions. A home-made plasmid carrying a $6 \times$ histidine tag followed by an $\mathrm{nTev}$ protease cleavage site in the $3^{\prime}$ region of the pET21d plasmid multi-cloning site (Novagen) (named pET21-His-Tev) was used for cloning procedures and expression of the recombinant porin. Escherichia coli strains $\mathrm{DH} 5 \alpha$ (Promega) and BL21( $2 \mathrm{DE} 3$ ) (Novagen) transformed with recombinant plasmids were grown in Luria-Bertani (LB) medium containing $100 \mu \mathrm{g}$ ampicillin $\mathrm{ml}^{-1}$ at $37^{\circ} \mathrm{C}$ and 200 r.p.m. overnight.

Cloning and expression of the endosymbiont porin gene in E. coli. Two primers were designed to amplify the endosymbiont porin gene by PCR. To ensure correct orientation into the multicloning site of the vector, the forward (5'-AATAGGATCCAAAAAAACTCTGCTTGCAGCTG-3') and reverse (5'-TATTAAGCTTTTAGAAGCGATGACGCATACC- $3^{\prime}$ ) primers carried restriction sites for BamHI and HindIII, respectively. Amplification of the DNA was achieved by PCR using elongase (Invitrogen). A $100 \mu \mathrm{l}$ reaction mixture contained $10 \mathrm{pmol}$ of each primer, $20 \mu \mathrm{l} 5 \times$ buffer, $200 \mu \mathrm{M}$ deoxynucleoside triphosphate mixture, $2.5 \mathrm{U}$ elongase and $100 \mathrm{ng}$ endosymbiont DNA as template. Amplification was performed using 35 cycles of denaturation at $94{ }^{\circ} \mathrm{C}$ for $2 \mathrm{~min}$, annealing at $55^{\circ} \mathrm{C}$ for $1 \mathrm{~min}$ and extension at $68{ }^{\circ} \mathrm{C}$ for $2 \mathrm{~min}$. The pET21d-His-Tev plasmid and the $1.2 \mathrm{~kb}$ amplified product were digested with BamHI and HindIII restriction endonucleases (New England Biolabs), followed by purification with a high-purity GFX PCR kit (GE Healthcare). The digested fragments were ligated with T4 DNA ligase (Promega), and the ligation product was transformed into $E$. coli $\mathrm{DH} 5 \alpha$ by electroporation. The recombinant plasmids were purified by the Wizard DNA Miniprep kit (Promega) and confirmed by automated DNA sequencing. To express the porin gene, the recombinant pET21d-His-Tev plasmid was transformed into E. coli BL21( $\lambda \mathrm{DE} 3)$. An overnight culture $(20 \mathrm{ml})$ was used to inoculate two flasks containing $11 \mathrm{LB}$ and $50 \mu \mathrm{g}$ ampicillin $\mathrm{ml}^{-1}$ each. The cells were grown at $37{ }^{\circ} \mathrm{C}$ with vigorous shaking (200 r.p.m.) until $\mathrm{OD}_{600} 0.8$ was reached. To induce protein expression, $0.5 \mathrm{mM}$ IPTG was added to the culture, which was further incubated for $5 \mathrm{~h}$ under the same conditions. Cells were collected by 
centrifugation at $6000 \mathrm{~g}$ for $20 \mathrm{~min}$ at $4{ }^{\circ} \mathrm{C}$, and the pellet was stored at $-20{ }^{\circ} \mathrm{C}$.

Purification of recombinant porin. Cell pellets from induced cultures were resuspended in buffer A $(50 \mathrm{mM}$ Tris $/ \mathrm{HCl}, \mathrm{pH} 8.0$, $100 \mathrm{mM} \mathrm{NaCl}, 5 \mathrm{mM} \beta$-mercaptoethanol) containing $1 \%$ Triton X100 and $1 \mathrm{mM}$ PMSF. Lysozyme and PMSF were added to final concentrations of $1 \mathrm{mg} \mathrm{ml}^{-1}$ and $1 \mathrm{mM}$, respectively, and the cell suspension was incubated for $30 \mathrm{~min}$ in a shaking ice bath. DNase and $\mathrm{MgCl}_{2}$ solutions were then added to final concentrations of $10 \mu \mathrm{g}$ $\mathrm{ml}^{-1}$ and $5 \mathrm{mM}$, respectively, and the lysate was further incubated for $30 \mathrm{~min}$ in the ice bath. Next, the lysate was subjected to repeated sonication, with six cycles of $30 \mathrm{~s}$ followed by cooling on ice, until a clearer lysate was obtained. The sample was centrifuged at $16000 \mathrm{~g}$ for $20 \mathrm{~min}$ at $4{ }^{\circ} \mathrm{C}$, and the supernatant was discarded (see Results). The pellet was solubilized in $20 \mathrm{ml}$ buffer B (buffer A containing $8 \mathrm{M}$ urea) with stirring at $4{ }^{\circ} \mathrm{C}$ overnight, and the recombinant protein was purified by affinity chromatography on two nickel-HisTrap HP columns (GE Healthcare) under denaturing conditions. Each column containing $5 \mathrm{ml} \mathrm{Ni}^{2+}$ resin was equilibrated with 10 volumes buffer $\mathrm{B}$, and the protein solution was loaded onto the columns. The columns were washed with five volumes of buffer B containing $20 \mathrm{mM}$ imidazole. The recombinant protein was then eluted by a concentration gradient of imidazole increasing from 0.01 to $0.5 \mathrm{M}$, and the fractions collected were analysed for protein content by SDSPAGE. Fractions containing pure recombinant protein were pooled and stored at $4{ }^{\circ} \mathrm{C}$.

Refolding of the recombinant porin. The urea-denatured protein was first diluted $1: 1$ with TEN buffer $(50 \mathrm{mM}$ Tris/ $\mathrm{HCl}, \mathrm{pH} 8.0$, $100 \mathrm{mM} \mathrm{NaCl}, 1 \mathrm{mM}$ EDTA) containing $10 \%$ amidosulfobetaine-14 (ASB-14; Calbiochem) and then sonicated for $10 \mathrm{~min}$ in a bath-type sonicator. Then, the sample was further diluted $1: 20$ with TEN buffer containing $0.5 \%$ ASB-14 using a calibrated peristaltic pump to deliver a slow flow rate to decrease the urea concentration gradually. Since the protein was highly pure, it was concentrated in an Amicon system using a $10 \mathrm{kDa}$ cut-off membrane. The protein concentration was calculated spectrophotometrically (using a molar absorption coefficient at $280 \mathrm{~nm}$ of $58790 \mathrm{M}^{-1} \mathrm{~cm}^{-1}$ ) and using Bradford kit assay (Sigma-Aldrich) and BSA as protein standard.

Spectroscopic analysis of the refolded recombinant porin. Fluorescence spectroscopic measurements of the unfolded protein in $8 \mathrm{M}$ urea and the refolded protein were carried out using a Hitachi F4500 spectrofluorometer. The excitation wavelength was fixed at $278 \mathrm{~nm}$, and the emission spectrum was recorded from 300 to $400 \mathrm{~nm}$. All experiments were performed at $25{ }^{\circ} \mathrm{C}$ unless otherwise stated. Circular dichroism (CD) analyses were carried out in a Chirascan spectropolarimeter (Applied Photophysics) at $25{ }^{\circ} \mathrm{C}$ in a $0.01 \mathrm{~cm}$ path length detachable quartz cuvette. Spectra were the mean of three scans at a $10 \mathrm{~nm} \mathrm{~min}{ }^{-1}$ speed, and the signal produced by the buffer solution was subtracted from the respective sample spectrum.

Gel-filtration chromatography. Gel-filtration chromatography was

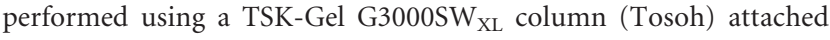
to an HPLC system (Akta Purifier, GE) with the absorbance wavelength fixed at $220 \mathrm{~nm}$. The system was equilibrated in PBS with a flow rate of $1 \mathrm{ml} \mathrm{min}$. Proteins used as molecular mass standards were thyroglobulin $(669 \mathrm{kDa})$, apoferritin $(443 \mathrm{kDa})$, $\beta$-amylase $(200 \mathrm{kDa})$, alcohol dehydrogenase $(150 \mathrm{kDa}), \quad B S A$ $(66 \mathrm{kDa})$, ovalbumin $(45 \mathrm{kDa})$ and carbonic anhydrase $(29 \mathrm{kDa})$. The protein standards were diluted in PBS to a final concentration of $1 \mathrm{mg} \mathrm{m}{ }^{-1}$, and the concentration of endosymbiont porin was $50 \mu \mathrm{M}$. Each protein was separately loaded onto the gel-filtration column using a $100 \mu \mathrm{l}$ loop.
Preparation of recombinant porin antiserum. Five-week-old $\mathrm{BALB} / \mathrm{c}$ male mice were inoculated by intraperitoneal injection with $100 \mu \mathrm{g}$ purified protein in Freund's complete adjuvant (Sigma) per animal. At 2 week intervals thereafter, they were given three intraperitoneal doses of $70 \mu \mathrm{g}$ recombinant protein with Freund's incomplete adjuvant (Sigma) per animal. Antisera were obtained 5 days after the last booster injection. An aliquot of animal serum was obtained before immunization.

Antibody purification by affinity. Serum was purified by antibodyantigen affinity on nitrocellulose membrane. Briefly, the purified recombinant protein separated on an SDS-polyacrylamide gel was transferred to a nitrocellulose membrane, which was then stained with Ponceau Rouge solution $(0.2 \%$ Ponceau S, $3 \%$ glacial acetic acid). Bands of the recombinant protein were removed using a scalpel, destained with distilled water and treated for $1 \mathrm{~h}$ with blocking solution (PBS and $3 \%$ BSA, pH 7.2). The antiserum was incubated with the membrane containing the recombinant protein at $4{ }^{\circ} \mathrm{C}$ for $48 \mathrm{~h}$, which was then washed three times in PBS, pH 7.2. Specific antibodies attached to the membrane were eluted with a solution of $0.2 \mathrm{M}$ glycine and $1 \mathrm{mM}$ EDTA, $\mathrm{pH} 4.0$, for $8 \mathrm{~min}$, which was further neutralized with a previously cooled $10 \mathrm{mM}$ Tris-base solution in sufficient volume to achieve $\mathrm{pH}$ 7.0.

Western blotting assay. Samples of the purified recombinant porin (10 $\mu \mathrm{g}$ per well) along with whole endosymbiont lysate $(15 \mu \mathrm{g}$ per well) and mitochondrial preparation $(15 \mu \mathrm{g}$ per well) were separated by $12 \%$ SDS-PAGE for $1 \mathrm{~h}$ at $30 \mathrm{~mA}$. The proteins were transferred onto a nitrocellulose membrane (Bio-Rad) by semidry blotting at $350 \mathrm{~mA}$ for $90 \mathrm{~min}$. Non-specific binding sites were blocked by incubating the membrane with $5 \%$ non-fat milk powder and $0.1 \%$ Tween-20 diluted in PBS, $\mathrm{pH} 8.0$, for $45 \mathrm{~min}$ at $4{ }^{\circ} \mathrm{C}$. Membranes were then incubated for $1 \mathrm{~h}$ with the purified polyclonal antiserum raised against the recombinant porin diluted 1:500 in blocking buffer. The membrane was washed three times with PBS and then incubated for $45 \mathrm{~min}$ with anti-mouse IgG secondary antibodyhorseradish peroxidase (HRP) conjugate (Pierce) diluted 1:4000 in blocking buffer. Bound antibodies were detected with the HRPconjugated mouse IgG as the secondary antibody and a SuperSignal West Pico Detection kit (Pierce).

Immunofluorescence assays. $C$. deanei cells were washed in PBS, $\mathrm{pH} 7.2$, and fixed for $30 \mathrm{~min}$ with $4 \%$ freshly prepared formaldehyde diluted in PBS. Cells were deposited on poly-L-lysine-treated microscope slides and permeabilized with $1.5 \%$ Triton X-100 in PBS, $\mathrm{pH} \mathrm{7.2,} \mathrm{for} 25 \mathrm{~min}$. The slides were incubated in blocking solution containing $1.5 \%$ BSA in PBS, pH 7.2, and then with purified anti-porin antibodies diluted $1: 5$ in blocking solution for $1 \mathrm{~h}$. The cells were washed and incubated for $45 \mathrm{~min}$ with FITC-conjugated anti-mouse IgG diluted 1:400 in blocking solution. The slides were mounted in $N$-propyl gallate, and serial image stacks $(0.2 \mu \mathrm{m} \mathrm{z}$ increments) were obtained at $100 \times$ (oil immersion 1.4 numerical aperture) with a motorized Olympus BX microscope equipped with differential interference contrast optics and an Orca $\mathrm{R}^{2}$ (Hamamatsu, Japan). All images were collected with CellM software (Olympus), and fluorescence images were deconvolved by using blind deconvolution with AutoQuant 2.0 software (Media Cybernetics). The preimmune serum was also tested as described above, and incubations without anti-porin antibodies were used as negative controls.

Ultrastructural immunocytochemistry. The parasites were fixed in $0.3 \%$ glutaraldehyde, $4 \%$ freshly prepared formaldehyde and $1 \%$ picric acid in $0.1 \mathrm{M}$ cacodylate buffer at $\mathrm{pH} 7.2$, and then dehydrated at $-20{ }^{\circ} \mathrm{C}$ in a graded series of ethanol solutions. The material was progressively infiltrated with Unicryl at lower temperatures, and resin polymerization was carried out in BEEM capsules at $-20{ }^{\circ} \mathrm{C}$ for 5 days under UV light. Ultrathin sections were obtained with a Leica 
ultramicrotome (Reichert Ultracuts) and grids containing the sections were treated as follows: $30 \mathrm{~min}$ in $50 \mathrm{mM} \mathrm{NH}_{4} \mathrm{Cl}$, followed by $30 \mathrm{~min}$ in blocking solution ( $1.5 \% \mathrm{BSA}, 0.5 \%$ teleostean gelatin, $0.02 \%$ Tween 20 in PBS, $\mathrm{pH} 8.0$ ) and $1 \mathrm{~h}$ in anti-porin purified antibodies diluted $1: 2$. The grids were further incubated for $30 \mathrm{~min}$ with $15 \mathrm{~nm}$ gold-labelled goat anti-mouse IgG (Sigma) diluted $1: 200$, washed in PBS and distilled water, and stained with uranyl acetate and lead citrate for observation in a Zeiss 900 transmission electron microscope. For control assays, incubation with the primary antiserum was omitted.

Electrophysiological analyses. Planar lipid bilayers were formed by folding two lipid monolayers over a hole $(110-150 \mu \mathrm{m}$ in diameter) made in a $25 \mu \mathrm{m}$-thick Teflon partition that separated two Teflon experimental chambers, as described in detail elsewhere (Homble et al., 2010). Bacterial polar lipids were from Avanti Polar Lipids. $\mathrm{Ag} / \mathrm{AgCl}$ electrodes connected in series with a salt bridge (1 M $\mathrm{KCl}$ in $1 \%$ agar) were used to connect the experimental chambers to the electronic equipment. The trans compartment was defined as the one connected to earth, and the voltage was applied to the cis compartment. For channel reconstitution in a planar lipid bilayer, proteins were added to the cis compartment. Unless otherwise indicated, experiments were performed in $1 \mathrm{M} \mathrm{KCl}, 10 \mathrm{mM}$ HEPES $(\mathrm{pH} 7.5)$. To measure the current-voltage relationship, a periodic symmetrical triangular voltage, $10 \mathrm{mHz}$ in frequency, from a Wavetek 39 waveform generator was applied across the membrane, and the current flowing through the membrane was amplified using a BLM 120 amplifier (BioLogic). Data were filtered at $300 \mathrm{~Hz}$ (five-poles linearized Tchebichev filter), digitized at $44.4 \mathrm{kHz}$ with a DRA 200 interface (BioLogic) and stored on compact disk for further processing using a homemade program written in the Matlab environment (The MathWorks). For selectivity measurements, the reversal potential (zero-current voltage) was set to zero in the presence of identical salt activity (0.5) on both sides of the membrane. Then, the cis compartment was perfused three times with its volume of a solution of different salt concentration, and the change of reversal potential was recorded. The ion selectivity was calculated by the Goldman-Hodgkin-Katz equation using the molal activities of ions (Hille, 1992). Data are shown as mean \pm SEM.

\section{RESULTS}

\section{Analysis of the endosymbiont porin-like protein sequence}

A single-copy gene sequence encoding a $45 \mathrm{kDa}$ porin-like protein was retrieved from the $C$. deanei endosymbiont genome database (GenBank accession no. HM480845; see Supplementary Fig. S3). An ExPASy BLAST2 search performed against the non-redundant (nr) database of GenBank revealed that the symbiont porin sequence presents high similarity to those described for $\beta$ proteobacteria of the genus Bordetella, which contains the possible ancestral bacterium ( $\mathrm{Du}$ et al., 1994). A multiple sequence alignment revealed that the porin-like amino acid sequence of the $C$. deanei symbiont showed $52 \%$ identity and $68 \%$ similarity with porin precursors of Bordetella pertussis and Bordetella bronchiseptica, and $51 \%$ identity and $67 \%$ similarity with the Bordetella parapertussis porin precursor, sharing 197 identical amino acids among those sequences. A porin from Burkholderia, a probably more distant genus, gave a lower identity of
$29 \%$ and similarity of $43 \%$ (Fig. 1). A search of the endosymbiont protein-encoding gene against the trypanosomatid complete genomes in GenBank showed no significant match.

The program SignalP 3.0 predicted a signal peptide (MKKTLLAAALVTSFAGVAQA, Fig. 1, in green) in the $\mathrm{N}$-terminal region of the porin-like protein of the endosymbiont with a score of 0.926 , well above the cutoff value of 0.52 for a signal peptide composed of 20 amino acids. This sequence shares about $80 \%$ identity and $90 \%$ positivity with signal peptides of other porins from the genus Bordetella (Fig. 1). Its presence suggests that the endosymbiont protein is processed before being targeted to its final destination (Pugsley, 1993; von Heijne, 1990). In addition, the last amino acid residue in the $\mathrm{C}$ terminus of the endosymbiont protein is a phenylalanine, a feature shared with other classical porins (Nikaido, 2003).

\section{The bacterial origin of the endosymbiont porin-like protein}

To investigate the origin of the endosymbiont protein, a phylogenetic tree was constructed based on the deduced amino acid sequences of several pore-forming proteins of evolutionarily divergent organisms (Fig. 2). These included eukaryotic and prokaryotic proteins, such as mitochondrial channels, classical porins and aquaporins. Sequences from Trypanosoma brucei and Trypanosoma cruzi were also included in order to investigate whether the endosymbiont protein is related to mitochondrial porins of trypanosomatid protozoa. In the resulting tree, the symbiont protein forms a well-defined cluster with classical bacterial porins of the genera Bordetella and Achromobacter (group I, distant from the cluster of porins of other bacterial species in group II). Thus, according to phylogenetic analysis, the symbiont porin-like protein is more closely related to Gram-negative porins than to the trypanosomatid proteins and animal/fungal VDACs that were chosen for comparative analysis (Fig. 2, groups III and VI, respectively).

\section{Structural characteristics of the endosymbiont porin-like protein}

After searching the Pfam and COG databases, the endosymbiont protein was clustered into the OM $\beta$-barrel protein superfamily (MBB clan), more specifically among the Gram-negative bacterial porins, in agreement with the phylogenetic tree in Fig. 2.

In order to support the predicted $\beta$-barrel structure, typical of bacterial porins, a 3D model was built for the endosymbiont OM protein. A BLAST search against PDB revealed that the structure of the anion-selective trimeric porin Omp32 from Delftia acidovorans (PDB entry 2FGR) was the best template available (Zachariae et al., 2006), showing $47 \%$ amino acid sequence similarity with the endosymbiont porin (see Supplementary Fig. S1). 
Endosymbiont protein B. parapertussis

B. pertussis

B. bronchiseptica

Burkholderia dolosa

Endosymbiont protein

B. parapertussis

B. pertussis

B. bronchiseptica

Burkholderia dolosa

Endosymbiont protein

B. parapertussis

B. pertussis

B. bronchiseptica

Burkholderia dolosa

Endosymbiont protein

B. parapertussis

B. pertussis

B. bronchiseptica

Burkholderia dolosa

Endosymbiont protein

B. parapertussis

B. pertussis

B. bronchiseptica

Burkholderia dolosa

Endosymbiont protein

B. parapertussis

B. pertussis

B. bronchiseptica

Burkholderia dolosa

Endosymbiont protein

B. parapertussis

B. pertussis

B. bronchiseptica

Burkholderia dolosa
MIKTLLAAALVTSFAGVAOAETAVNLYGLIDTGVNVNTVEVRDFR------RVKHKISRVGPVSGAOSGS MKKTLLAAALLAGFAGAAQAETSVTLYGIIDTGIGYNDVDFKVKGANADGSDFKYNHSRFGMINGVQNGS MKKTLLAAALIAGEAGAAOAETSVTLYGIIDTGIGYNDVDFKVKGANADDSDFKYNHSRFGMINGVONGS MKKTLLAAALLAGFAGAAQAETSVTLYGI IDTGIGYNDVDFKVKGANADGSDFKYNHSRFGMINGVQNGS MNKQLIAAPLLLSLAGIASAQGSVTLYGIVDAGVTYRSNERAGAP------RAYTGHSNVGLTTGNLSGS

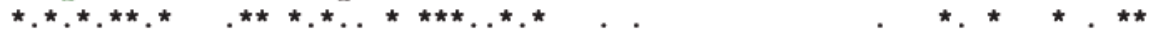

RWGLKGTEEIGNGLRAEFVLEGGFNSGNGDAAOTORIFGROVTVGVANDAWGRIDIGROTNVASKYFADI RWGLRGTEDLGDGLQAVFQLESGFSSANGNSAQDGRLFGRQATIGLQSESWGRLDFGRQTNIASKYFGSI RWGLRGTEDLGDGLQAVFQLESGFNSGNGNSAQDGRLFGRQATIGLQSESWGRLDFGRQTNIASKYFGSI RWGLRGTEDLGDGLQAVFQLESGFNSGNGNSAQDGRLFGRQATIGLQSESWGRLDFGRQTNIASKYFGSI RWGIKGSEDLGGGLRALFVLENGEDIANGTSGQGGRQFGRQAFVGLGSDRYGSITLGRQYTSLDDFVSPV

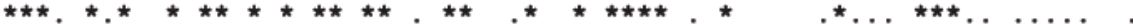

DPFKGGF-------EOSAIGMSIGSSNVRYDNMIMYOTPSFRGIDIGVGYSFSVDTKSSKSEHVTVNNAF DPFGAGF------GQANIGMGMSAMNTVRYDNMVMYTPSYSGFQFGIGYSFSANDKDADAVNRVGF--DPFGAGF------GQANIGMGMSAMNTVRYDNMVMYQTPSYSGFQFGIGYSFSANDKDADAVNRVGF--DPFGAGF------GQANIGMGMSAMNTVRYDNMVMYQTPSYSGFQFGIGYSFSANDKDADAVNRVGF--GPSSFVGG-----FGAHPGDIDDLDQTARVDNSIKYTSANYSGFTFGALYGFGGQPG------------

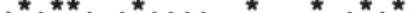

SAEEAANWRTNENDRAFTTGIRYSNGPVVATASFDYVKGSKRRVER--------------------DAYF

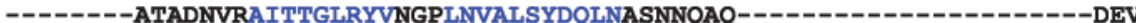
--------ATADNVRAITTGLRYVNGPLNVALSYDQLNASNNQAQ----------------------GEV -------ATADNVRAITTGLRYVNGPLNVALSYDQLNASNNQAQ---------------------GEV --------SITQRNTWSVGAAYAAGPLRVGVGYERSDNSKTGASDTTIGKWQSTDDGLFNSSINEGYAS $\ldots .^{\star} \ldots{ }^{\star \star}$

248 DVSPCSYAVGGAYDFDVAKVSVAYAKTMDGWIG---ALN-VDGYRDLIGLSRLITEYADGFRSSSYVVGV DATPRYGICGSYDFEVVI DATPRSYGLGGSYDFEVVKI.ALAYARTTDGWFGGQGYPVAVTLPSGDKFGGFGVNTFADGFKANSYMVGI DATPRSYGLGGSYDFEVVKLALAYARTTDGWFGGOGYPVAVTLPSGDKFGGFGVNTFADGFKANSYMVGI

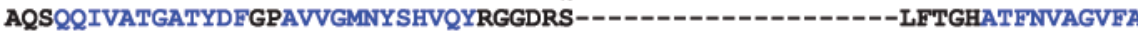
$\ldots \ldots$

SAPINETSNVFGSWQRVSVNAKPKGARLTGDNDSMNVYSVGYTQDLSKRTNLYAYGSYASDYAFL----SAPIGGASNVFGSWOMVDPSNDKL----TGGDEKMNVFSLGYTYDLSKRTNLYAYGSYAKNFAFL----SAPIGGASNVFGSWQMVDP---KL----TGGDEKMNVFSLGYTYDLSKRTNLYAYGSYAKNFAFL----SAPIGGASNVFGSWOMVDPSNDKL----TGGDEKMNVFSLGYTYDLSKRTNLYAYGSYAKNFAFL----RWNVRPQTQLFAGYSYTRGGEVDG----IDERAQYHNVTLGAIYDLSKRTSVYLLGAYQHASGTTLDALG$$
\cdots
$$

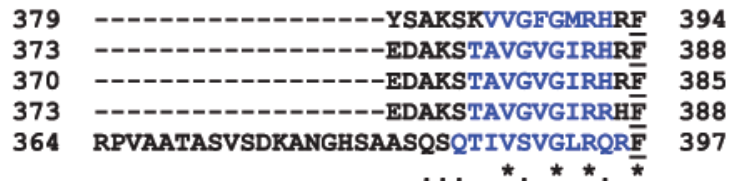

Fig. 1. Multiple sequence alignment of the endosymbiont protein and porins from the genera Bordetella and Burkholderia. The alignment reveals a number of conserved features. Asterisks mark residues conserved among all sequences. Dots represent positions conserved only among the endosymbiont protein and porins of the genus Bordetella. Amino acid residues in green type indicate signal peptide sequences. Amino acid residues in blue and red type are predicted to be $\beta$-sheets and $\alpha$-helices, respectively, by PSIPRED. Amino acids in underlined type represent the fully conserved C-terminal phenylalanine typical of classical bacterial porins. Accession numbers: B. parapertussis NP_885555, B. pertussis NP_879650, B. bronchiseptica NP_890377, Burkholderia dolosa ZP 04947895.

We used the above protein as template, and its sequence was aligned with the endosymbiont porin using PSIPRED secondary structure predictions to guide the alignment, as they share low sequence identity. It is worth mentioning that the use of PSIPRED accurately predicted, to more than $85 \%$, the $\beta$-sheet residues in the crystal structure of Omp32 from $D$. acidovorans, thus suggesting that the secondary structure predicted for the endosymbiont protein using the same tool might be very close to its real topology (see Supplementary Fig. S2). The 3D model of the endosymbiont OM protein had good stereochemical quality, with $92 \%$ of the residues within allowed core regions of the Ramachandran plot. Furthermore, when compared with the structure of the Omp32 template, an RMSD of $1.7 \AA$ was obtained, also indicating the good quality of the model. 


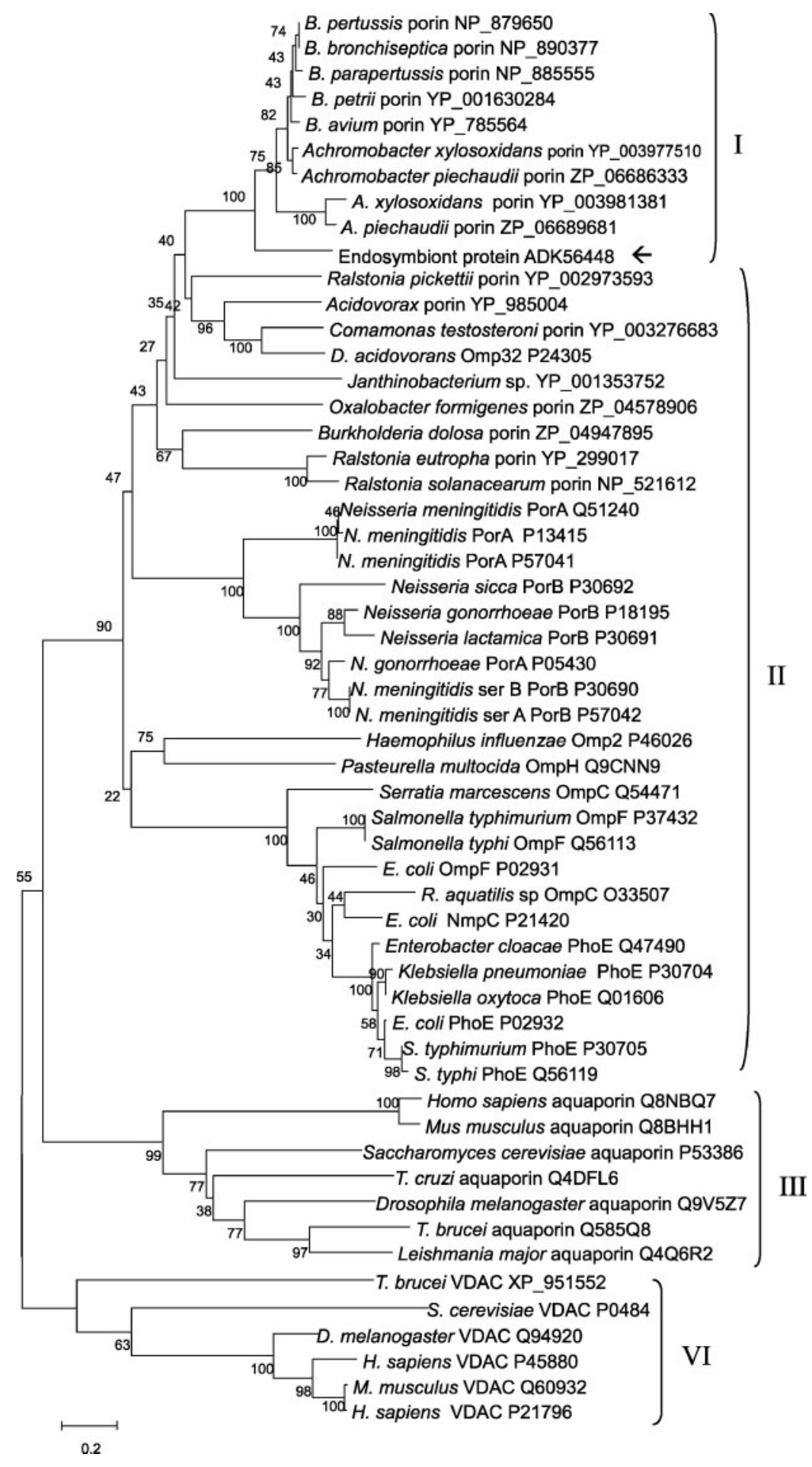

II

Fig. 2. Phylogenetic analysis of the C. deanei endosymbiont porin. The endosymbiont porin (arrow) is closely related to Bordetella sp. porins. Group I, porins of the genera Bordetella and Achromobacter; group II, porins from other bacteria; group III, aquaporins of eukaryotic origin; group IV, mitochondrial VDAC proteins. Accession numbers of the sequences used are indicated.
The secondary structure analysis revealed that the endosymbiont protein forms $\beta$-strand structures similar to those of the Omp32 monomer (Supplementary Fig. S1) (Zachariae et al., 2006). However, two additional $\beta$-strands were predicted in the endosymbiont protein, between residues 278-286 and 289-298, which have no corresponding motifs in Omp32, as shown in the comparative model (Supplementary Fig. S1, blue boxes). The OM porin-like protein 3D model shows seven periplasmic $\beta$-turns and eight exoplasmic loops that connect the $16 \beta$-strands composed of $8-11$ amino acids and tilted $35^{\circ}$ to $40^{\circ}$ in relation to the barrel axis (Supplementary Fig. S2a). The superposition of the Omp32 3D structure (Supplementary Fig. S2b) on the endosymbiont 3D porin-like protein model revealed structural similarity (Supplementary Fig. S2c, d). The L3 loop is particularly long and bends inside the pore, whereas the L2 
loop plays an important role in stabilizing the trimeric conformation of several bacterial porins (Supplementary Fig. S2c) (Nikaido, 2003; Zeth \& Thein, 2010).

\section{Conformational analysis of the refolded endosymbiont porin}

In order to carry out the biochemical and cellular characterization of the endosymbiont porin, its gene was cloned into a pET vector used for protein expression in $E$. coli. At the end of the induction, it was observed that the porin was expressed as an inclusion body, which required the use of urea-denaturing buffer for its solubilization. The porin was then refolded by a slow dilution procedure in TEN buffer containing $10 \%$ ASB-14. Afterwards, the tertiary structure conformational analysis of the purified endosymbiont porin was carried out by fluorescence spectroscopy of tryptophan residues. Tryptophan is an excellent intrinsic fluorescent probe because its fluorescence spectrum changes as it becomes more exposed to solvent, shifting its emission spectrum to higher wavelengths. The endosymbiont porin protein contains five tryptophan residues, and as expected, a peak at approximately $336 \mathrm{~nm}$ was observed in the emission spectrum of the protein after refolding, whereas the ureadenatured protein spectrum presented a peak at a higher wavelength, or more precisely, at $355 \mathrm{~nm}$ (Fig. 3a). The secondary structure of the refolded porin was evaluated by $\mathrm{CD}$ analysis, which showed a typical $\beta$-sheet spectrum with a single negative ellipticity peak at $217 \mathrm{~nm}$ (Fig. 3b). While the fluorescence spectroscopy technique revealed that the unfolded and the refolded proteins present different conformational states, the CD spectrum clearly demonstrated that the endosymbiont porin adopts mainly the $\beta$ sheet conformation found in other bacterial porins (Nikaido, 1993).

The oligomeric state of the refolded endosymbiont porin at $50 \mu \mathrm{M}$ concentration was evaluated by gel-filtration chromatography (Fig. 3c). The peak of the protein solution elution (continuous black curve) emerged at the same time as the $45 \mathrm{kDa}$ ovalbumin protein (dot-dash blue curve, number 6), indicating that the endosymbiont porin was predominantly monomeric in solution at the concentration used.

\section{Immunodetection of the porin in C. deanei endosymbiont-containing cells and in the bacterium envelope}

Cell extracts of $C$. deanei strains, endosymbiont-containing and endosymbiont-free, as well as symbiont and mitochondrial fractions, were used in immunoblotting assays (Fig. 4). Antibodies raised against the symbiont porin detected a single polypeptide of $\sim 45 \mathrm{kDa}$ only in the samples from symbiont-bearing cells (lane 2) and in endosymbiont fractions (lane 5). Moreover, the porin was immunodetected in an extract of the endosymbiont membrane (lane 7) but not among the proteins in the soluble fraction (lane 6). It is worth mentioning that the apparent molecular mass of the recombinant endosymbiont protein was slightly higher than that of the protein molecule found in the endosymbiotic bacterium because the former carries $6 \times$ his tag and tev protease cleavage site sequences.

\section{Immunolocalization of the porin in the envelope of the C. deanei endosymbiont}

Polyclonal antibodies raised against the purified endosymbiont porin were also used to determine its distribution in C. deanei cells. Data obtained by immunofluorescence microscopy showed that the antibodies exclusively recognized the endosymbiont, as no other organelle or host-cell structure was labelled (Fig. 5a-d). Ultrastructural immunocytochemistry analysis confirmed the envelope localization of the endosymbiont porin (Fig. 5e), because the majority of the gold particles were found distributed around the envelope, especially in the $\mathrm{OM}$, and few of them were seen over the endosymbiont matrix (Fig. 5f).

\section{The pore-forming nature of the C. deanei endosymbiont porin}

In order to evaluate the pore-forming ability of the endosymbiont porin, the recombinant protein was reconstituted in a planar lipid bilayer made of bacterial polar lipids (mainly phosphatidylethanolamine and phosphatidyglycerol). At low voltages, the conductance of the channel was constant (Fig. 6). Discrete decreases in current corresponding to channel closure were observed at voltages higher than $\pm 100 \mathrm{mV}$ (Fig. 6a, b) and were used to calculate the channel conductance. These closures were often irreversible. The data suggest a conductance of $1.22 \pm 0.08 \mathrm{nS}(n=14)$ in $1 \mathrm{M} \mathrm{KCl}$. Selectivity measurements were assessed in the presence of a $\mathrm{KCl}$ concentration difference across the membrane $(1 \mathrm{M} / 0.1 \mathrm{M} \mathrm{KCl}$, trans/ cis). Under these conditions, the zero-current potential was $+17.0 \pm 0.7 \mathrm{mV}(n=7)$ (Fig. $6 \mathrm{c}$ ), corresponding to a permeability ratio $\mathrm{P}_{\mathrm{K}}: \mathrm{P}_{\mathrm{Cl}}$ of $2.4 \pm 0.1 \quad(n=7)$. Thus, the endosymbiont porin displays a slight preference for cations over anions. No characteristic voltage-dependent closure typical of trimeric bacterial porins was observed, thus suggesting that it might exist as a monomer in the endosymbiont membrane as already observed in the gelfiltration chromatography.

\section{DISCUSSION}

Endosymbiosis in trypanosomatid protozoa constitutes an excellent biological model for studying the relationship between prokaryotes and eukaryotes and the symbiotic origin of organelles. A close and prolonged association has generated a mutual dependence between $C$. deanei and the endosymbiont bacterium such that the prokaryote is unable to survive and replicate once isolated from the 

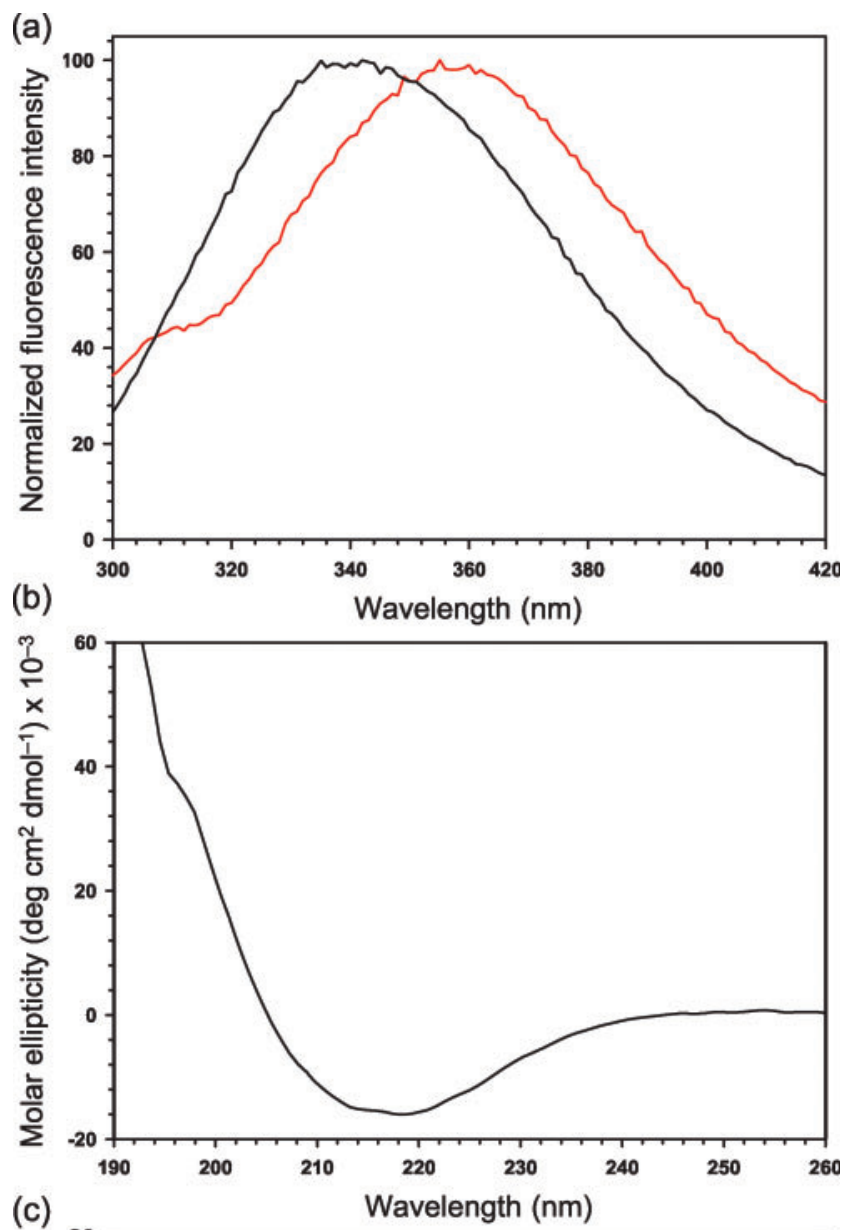

(c)

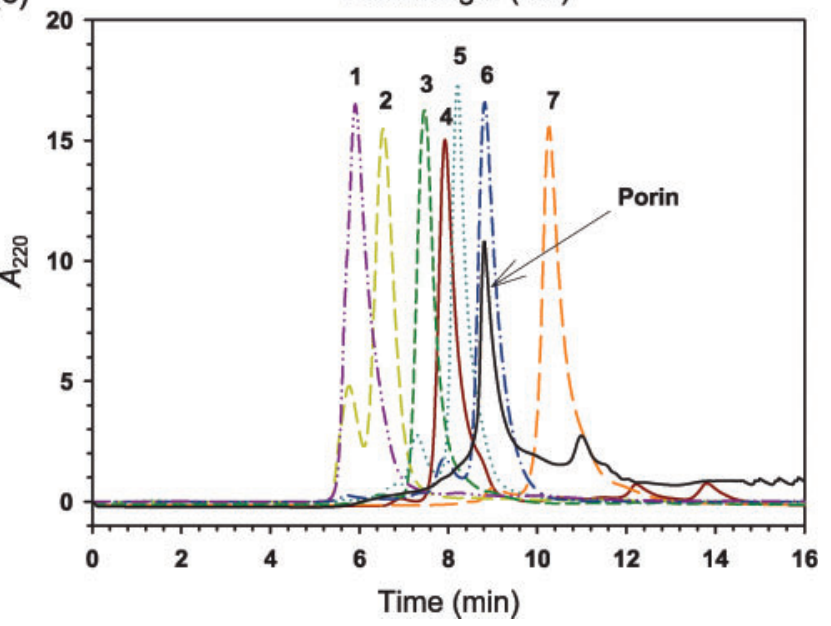

Fig. 3. Conformational analysis of the endosymbiont protein. (a) Effect of urea on folding of the recombinant porin at $5 \mu \mathrm{M}$ concentration monitored by Trp fluorescence spectra in TEN buffer (black line) and in $8 \mathrm{M}$ urea (red line) at $25^{\circ} \mathrm{C}$. (b) CD spectral analysis of the refolded porin in TEN buffer containing $0.5 \%$ ASB-14. (c) Gel-filtration chromatography in a TSK-Gel G3000SW $\mathrm{XL}_{\mathrm{C}}$ column of the recombinant porin and molecular mass standards: solutions of the porin protein and standards at $50 \mu \mathrm{M}$ and $1 \mathrm{mg} \mathrm{ml}^{-1}$, respectively, were separately applied onto the column, and the protein elution time relative to the molecular mass standards was determined. The endosymbiont protein peak (unbroken black line) emerged at the same time as ovalbumin at $45 \mathrm{kDa}$ (discontinuous blue line). Other proteins used as mass standards are shown: 1, thyroglobulin (669 kDa); 2, apoferritin (443 kDa); 3, $\beta$-amylase (200 kDa); 4, alcohol dehydrogenase (150 kDa); 5 , BSA (66 kDa); 6 , ovalbumin (45 kDa); 7, carbonic anhydrase (29 kDa). 


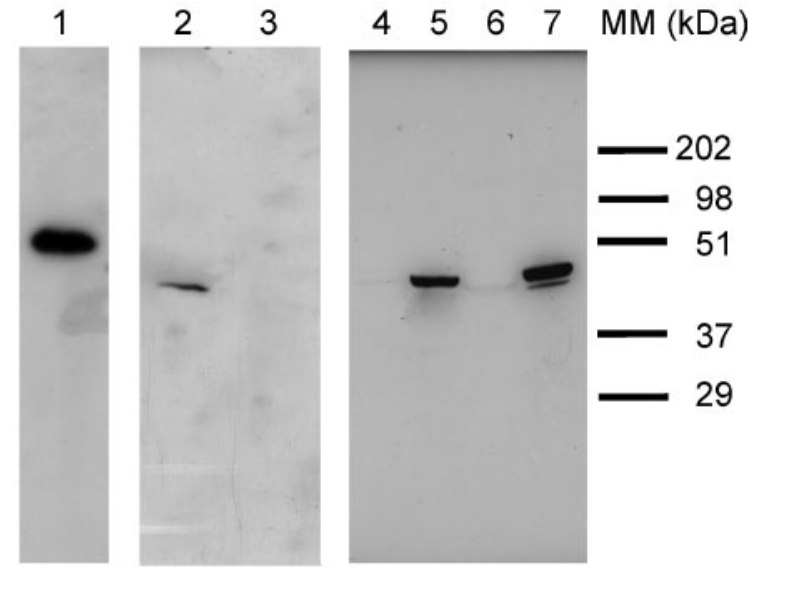

Fig. 4. Subcellular localization of the C. deanei endosymbiont porin. Western blotting using polyclonal antibodies against (1) recombinant purified endosymbiont porin, (2) C. deanei total protein extract, (3) protein extract of an endosymbiont-free C. deanei strain, (4) total protein extract of the C. deanei mitochondrial fraction, (5) endosymbiont total protein extract, (6) soluble proteins and (7) membrane protein extracts of the C. deanei endosymbiont. MM, molecular mass marker.

host, and cured or aposymbiotic trypanosomatids are incapable of colonizing insects (reviewed by Motta, 2010).

The endosymbiont is enclosed by two unit membranes as in Gram-negative species; however, the envelope of this bacterium presents typical features, such as a reduced cell wall, which has also been described in many obligate intracellular bacteria and may facilitate the metabolic exchanges with host cells (Corsaro et al., 1999; Goebel \& Gross, 2001). Little is known about the protein composition of the endosymbiont envelope, which might account for $5-10 \%$ of the whole protein content of the host trypanosomatid (Novak et al., 1988). In this work, we combined different approaches to characterize the $C$. deanei endosymbiont porin. This newly identified protein might be responsible for essential metabolic exchanges between the symbiont and the host cell, since it is the only porin present in the symbiotic bacterium OM (according to a genome-based prediction).

Immunocytochemical analysis showed that the identified porin specifically localizes in the symbiotic bacterium and not in host cell structures. Using antibodies against the endosymbiont porin, labelling was seen in the cell matrix, but was mainly localized at the prokaryote envelope. This is in agreement with the hypothesis that channel-forming proteins are synthesized in the cytoplasm and then translocated across the IM, where they remain facing the periplasmic side before reaching the OM (Ruiz et al., 2006).

Secondary structure prediction analysis revealed that the endosymbiont OM protein shares features with some Gramnegative bacterial porins. In these organisms, distinct classes
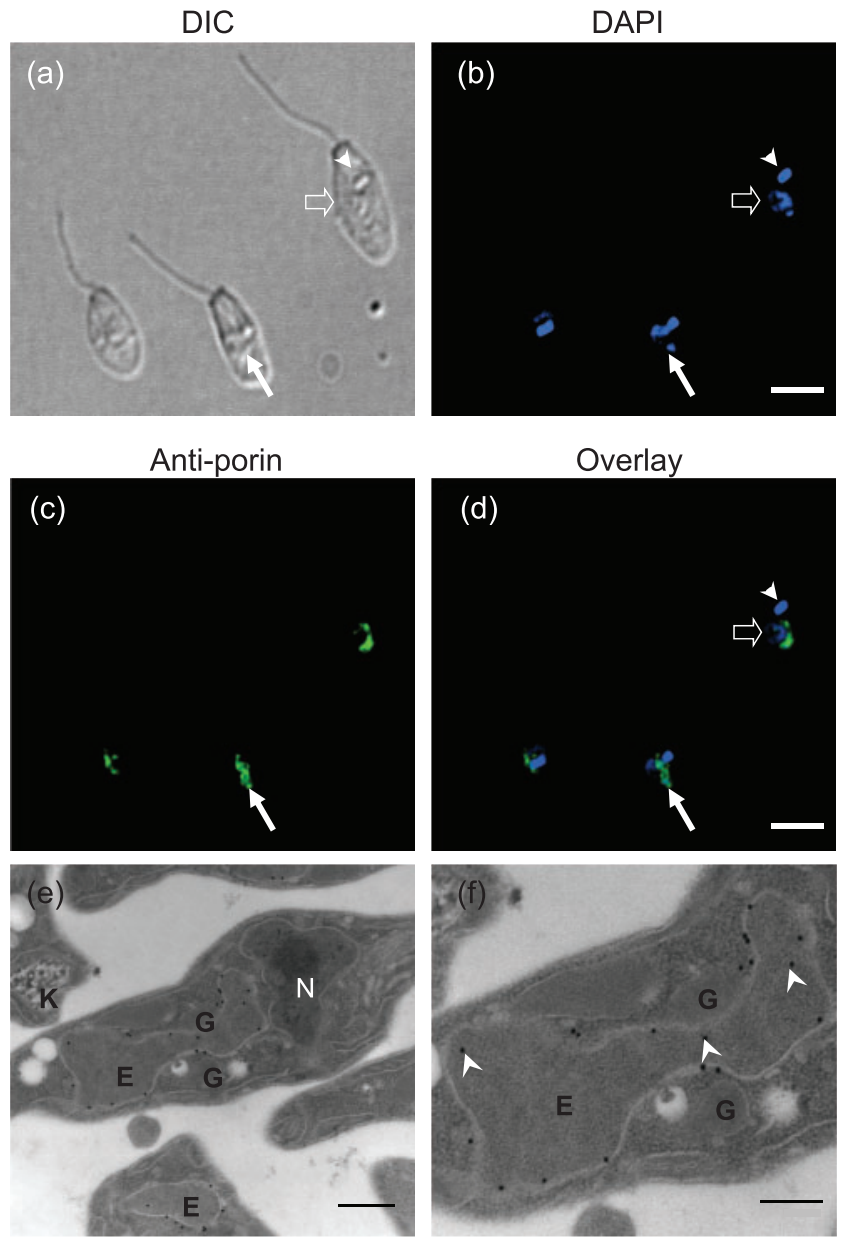

Fig. 5. Immunolocalization of C. deanei, showing the localization of the endosymbiont porin by the purified anti-porin-like antibodies. (a-d) Immunofluorescence assays. (a) Differential interference contrast microscopy (DIC), (b) DAPI, (c) endosymbiont porin detection, (d) overlay. White arrows indicate the endosymbiont, arrowheads point to the kinetoplast and the open arrow indicates the nucleus. Bars, $1.5 \mu \mathrm{m}$. (e, f) Ultrastructural immunocytochemistry. (e) Specific labelling of the endosymbiont $(E)$ and its proximity to the nucleus $(N)$ and glycosomes $(G) ;(f)$ at higher magnification, preferential labelling at the endosymbiont $\mathrm{OM}$ is observed. Arrowheads indicate labelling in the bacterial matrix. Bars, $0.5 \mu \mathrm{m}$ in (e) and $0.25 \mu \mathrm{m}$ in (f).

of channel-forming proteins have been described. According to crystal structure analyses, classical or general diffusion porins usually contain 16 transmembrane $\beta$-strands, whereas specific porins are mostly composed of $18 \beta$-strands per molecule, and the siderophore receptor FepA spans the membrane via $22 \beta$-strands (Ferguson et al., 2002; Nikaido, 1993). Unlike classical porins, the endosymbiont porin presents 18 instead of $16 \beta$-strands that probably span the symbiont phospholipid bilayer. The endosymbiont OM porin appears to exist as a monomer, at least under the conditions tested. This type of structural arrangement has been observed in other bacterial porins such as OmpG of $E$. 

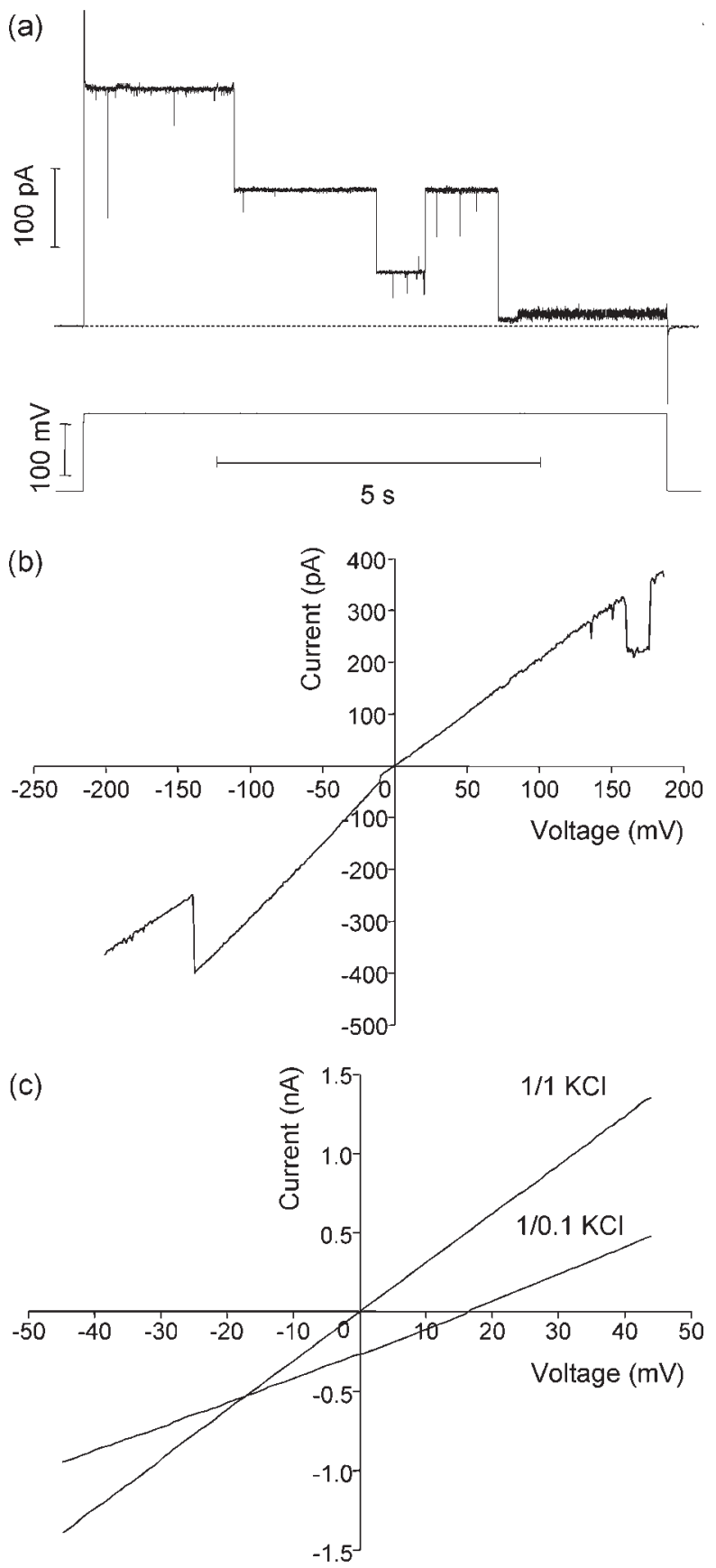

Fig. 6. Electrophysiology of the recombinant protein. The recombinant channel was reconstituted in a planar lipid bilayer formed from bacterial lipids. (a) Typical time-course of the current flowing through a membrane held at $+150 \mathrm{mV}$. The dashed line indicates the zero-current level. (b) Current-voltage curve recorded in a symmetrical $1 \mathrm{M} \mathrm{KCl}$ solution on both sides of the membrane channel. Closures were observed at high positive and negative voltages. (c) Current-voltage curve recorded in a symmetrical $1 \mathrm{M}$ $\mathrm{KCl}$ solution and then in an asymmetrical $1 \mathrm{M} / 0.1 \mathrm{M}$ (trans/cis) solution. The zero-current voltage (reversal potential) is zero under symmetrical conditions and shifts to a positive value after a decrease of the concentration of the cis compartment to $0.1 \mathrm{M} \mathrm{KCl}$, indicating a preferred selectivity for cations. In all cases solutions were buffered with $10 \mathrm{mM}$ HEPES at $\mathrm{pH}$ 7.5. coli. Interestingly, unlike the endosymbiont porin, OmpG appears to lack the large loop 3 that is ubiquitous among classical trimeric porins (Fajardo et al., 1998; Nikaido, 2003). However, we cannot rule out the possibility that the endosymbiont porin forms an unstable trimeric structure even at room temperature, as described for MOMP, a major $45 \mathrm{kDa}$ porin of Campylobacter jejuni, which is also monomeric, comprising 18 transmembrane $\beta$-strands (Nikaido, 2003).

To gain more information about the endosymbiont porin structure, we built a $3 \mathrm{D}$ model using Omp32 from $D$. acidovorans as a template. Despite the differences in their $\beta$-strand-forming abilities, as mentioned above, the $3 \mathrm{D} \beta$ barrel model proposed for the endosymbiont protein and the Omp32 $16 \quad \beta$-barrel structure share great topological similarity, with overlaps of corresponding $\beta$-strands. The 3D model allowed us to infer that at least the modelled parts of the protein could adopt a $\beta$-barrel fold that does not contain major stereochemical clashes. The electrophysiological analysis showed that the endosymbiont protein forms an ion channel across the lipid bilayer with weak selectivity for cations over anions. However, as observed for other porins, this does not exclude the possibility that the protein could transport anions under certain conditions (Nikaido, 2003). These findings together support the proposed $\beta$-barrel structure of the endosymbiont $\mathrm{OM}$ protein and confirm its ability to function as a diffusion pore across the $\mathrm{OM}$, or, more precisely, its porin nature.

Porins represent ancient proteins whose functions could have benefited cells early in evolution. They are good examples of proteins that evolved to perform several functions, regulating cell selectivity and requirements without undergoing great architectural rearrangements (Pohorille et al., 2005). They are commonly found in the OM of bacteria (Nikaido, 1992) and in archaea (Koebnik et al., 2000), as well as in organelles of symbiotic origin such as leaf peroxisomes, mitochondria and chloroplasts (Bölter \& Soll, 2001; Burghardt et al., 2007; Mannella, 1992; Rachel et al., 2002; Reumann et al., 1996). In eukaryotic organelles, porins allow the passage of a variety of essential intermediates for many cellular functions, implying that they are involved in the integration of subcellular structures into the metabolism of the eukaryotic cell. For instance, leaf peroxisomes contain a specific porin that transports malate (Reumann et al., 1996), mitochondrial VDACs control the OM permeability, allowing the diffusion of nucleotides and several other substrates (Liu \& Colombini, 1991, 1992), whereas plastid porins seem to be involved in the transport of amino acids and nitrogen compounds (Bölter \& Soll, 2001).

Molecular phylogenetic analysis revealed that the C. deanei endosymbiont porin forms a well-defined cluster with porins of Bordetella, which is considered to be the ancestral bacterial genus of the trypanosomatid endosymbiont. Moreover, it seems to be phylogenetically closely related 
to Gram-negative porins, being less related to the animal, fungal and trypanosomatid channel-forming proteins. It is worth considering that plastids and mitochondria likewise descended from prokaryotic progenitors; thus, their OMs maintain essential features of the bacterial OM, including the $\beta$-barrel structures of the porins (Duy et al., 2007; Gross \& Bhattacharya, 2009; Hewitt et al., 2011).

These findings represent a remarkable example of convergence in the evolution of the symbiotic bacteria-derived organelles (Gross \& Bhattacharya, 2009). Recently, it was shown that a pore-forming complex promotes interaction between cells of the species Ignicoccus hospitalis, the smallest archaeal cell known so far, and its symbiont Nanoarcheum equitans (Burghardt et al., 2007). Another report has described the importance of an aquaporin for the formation of ectomycorrhizae, a tight association between tree roots and soil fungi. In this case, the symbiotic fungus enhances water transport to plants through water pores, resulting in increased nutrient uptake, higher $\mathrm{CO}_{2}$ fixation and more efficient photosynthesis (Marjanović et al., 2005).

Therefore, it is conceivable that the increased permeability of the endosymbiont OM observed elsewhere (Zientz et al., 2004) and the porin described herein allow the symbiont access to $C$. deanei-derived nutrient factors. Conversely, some endosymbiont metabolic intermediates might cross the cell envelope through the same structures to complete essential biosynthetic pathways of the host protozoan. Thus, the endosymbiont porin channel might mediate substantial transport of solutes and substrates across its cellular membrane in order to maintain a close symbiotic relationship with the host cell. Further work is required to establish roles for this protein in the physiology of the endosymbiont and/or in its mutualistic association with the host protozoan.

\section{ACKNOWLEDGEMENTS}

We would like to thank Christian Probst and Marco Aurelio Krieger for providing the porin gene sequence. We would also like to thank Francisco J. R. Souza and Paulo Roberto Junior for their technical assistance. This investigation received financial support from Conselho Nacional de Desenvolvimento Científico e Tecnológico (CNPq), Instituto Nacional de Ciência e Tecnologia em Bioimagens e Biologia Estrutural (INCT-BBE) and Fundação Carlos Chagas Filho de Amparo à Pesquisa do Estado do Rio de Janeiro (FAPERJ). F. H. is a Research Director from the Fonds de la Recherche Scientifique (FRS-FNRS) (Belgium).

\section{REFERENCES}

Alfieri, S. C. \& Camargo, E. P. (1982). Trypanosomatidae: isoleucine requirement and threonine deaminase in species with and without endosymbionts. Exp Parasitol 53, 371-380.

Altschul, S. F., Gish, W., Miller, W., Myers, E. W. \& Lipman, D. J. (1990). Basic local alignment search tool. J Mol Biol 215, 403-410.

Bendtsen, J. D., Nielsen, H., von Heijne, G. \& Brunak, S. (2004). Improved prediction of signal peptides: SignalP 3.0. J Mol Biol 340, 783-795.
Berman, H. M., Westbrook, J., Feng, Z., Gilliland, G., Bhat, T. N., Weissig, H., Shindyalov, I. N. \& Bourne, P. E. (2000). The Protein Data Bank. Nucleic Acids Res 28, 235-242.

Bölter, B. \& Soll, J. (2001). Ion channels in the outer membranes of chloroplasts and mitochondria: open doors or regulated gates? EMBO J 20, 935-940.

Burghardt, T., Näther, D. J., Junglas, B., Huber, H. \& Rachel, R. (2007). The dominating outer membrane protein of the hyperthermophilic Archaeum Ignicoccus hospitalis: a novel pore-forming complex. Mol Microbiol 63, 166-176.

Camargo, E. P. \& Freymuller, E. (1977). Endosymbiont as supplier of ornithine carbamoyltransferase in a trypanosomatid. Nature 270, 52-53.

Colombini, M. (2004). VDAC: the channel at the interface between mitochondria and the cytosol. Mol Cell Biochem 256-257, 107-115.

Corsaro, D., Venditti, D., Padula, M. \& Valassina, M. (1999). Intracellular life. Crit Rev Microbiol 25, 39-79.

Dolezal, P., Likic, V., Tachezy, J. \& Lithgow, T. (2006). Evolution of the molecular machines for protein import into mitochondria. Science 313, 314-318.

Du, Y., McLaughlin, G. \& Chang, K. P. (1994). 16 S ribosomal DNA sequence identities of $\beta$-proteobacterial endosymbionts in three Crithidia species. J Bacteriol 176, 3081-3084.

Duy, D., Soll, J. \& Philippar, K. (2007). Solute channels of the outer membrane: from bacteria to chloroplasts. Biol Chem 388, 879-889.

Efron, B., Halloran, E. \& Holmes, S. (1996). Bootstrap confidence levels for phylogenetic trees. Proc Natl Acad Sci U S A 93, 1342913434 .

Eswar, N., Webb, B., Marti-Renom, M. A., Madhusudhan, M. S., Eramian, D., Shen, M. Y., Pieper, U. \& Sali, A. (2006). Comparative protein structure modeling using Modeller. Curr Protoc Bioinformatics Chapter 5, 5, 6.

Fajardo, D. A., Cheung, J., Ito, C., Sugawara, E., Nikaido, H. \& Misra, R. (1998). Biochemistry and regulation of a novel Escherichia coli K-12 porin protein, OmpG, which produces unusually large channels. J Bacteriol 180, 4452-4459.

Ferguson, A. D., Chakraborty, R., Smith, B. S., Esser, L., van der Helm, D. \& Deisenhofer, J. (2002). Structural basis of gating by the outer membrane transporter FecA. Science 295, 1715-1719.

Finn, R. D., Tate, J., Mistry, J., Coggill, P. C., Sammut, S. J., Hotz, H. R., Ceric, G., Forslund, K., Eddy, S. R. \& other authors (2008). The Pfam protein families database. Nucleic Acids Res 36 (Database issue), D281-D288.

Frossard, M. L., Seabra, S. H., DaMatta, R. A., de Souza, W., de Mello, F. G. \& Machado Motta, M. C. (2006). An endosymbiont positively modulates ornithine decarboxylase in host trypanosomatids. Biochem Biophys Res Commun 343, 443-449.

Goebel, W. \& Gross, R. (2001). Intracellular survival strategies of mutualistic and parasitic prokaryotes. Trends Microbiol 9, 267-273.

Gross, J. \& Bhattacharya, D. (2009). Mitochondrial and plastid evolution in eukaryotes: an outsiders' perspective. Nat Rev Genet 10, 495-505.

Guex, N. \& Peitsch, M. C. (1997). SwISS-MODEL and the SwissPdbViewer: an environment for comparative protein modeling. Electrophoresis 18, 2714-2723.

Hewitt, V., Alcock, F. \& Lithgow, T. (2011). Minor modifications and major adaptations: the evolution of molecular machines driving mitochondrial protein import. Biochim Biophys Acta 1808, 947-954.

Hille, B. (1992). Ionic Channel of Excitable Membranes, 2nd edn. Sunderland, MA: Sinauer Associates Inc. 
Homble, F., Mlayeh, L. \& Leonetti, M. (2010). Planar lipid bilayers for electrophysiology of membrane-active peptides. In Membrane-Active Peptides: Methods and Results on Structure and Function, vol. 9, pp. 281-320. Edited by M. Castanho. La Jolla, CA: IUL Publishers.

Jones, D. T. (1999). Protein secondary structure prediction based on position-specific scoring matrices. J Mol Biol 292, 195-202.

Klebba, P. E. \& Newton, S. M. (1998). Mechanisms of solute transport through outer membrane porins: burning down the house. Curr Opin Microbiol 1, 238-247.

Koebnik, R., Locher, K. P. \& Van Gelder, P. (2000). Structure and function of bacterial outer membrane proteins: barrels in a nutshell. Mol Microbiol 37, 239-253.

Kumar, S., Nei, M., Dudley, J. \& Tamura, K. (2008). MEGA: a biologistcentric software for evolutionary analysis of DNA and protein sequences. Brief Bioinform 9, 299-306.

Laskowski, R. A., MacArthur, M. W., Moss, D. S. \& Thornton, J. M. (1993). PROCHECK: a program to check the stereochemical quality of protein structures. J Appl Cryst 26, 283-291.

Lemasters, J. J. \& Holmuhamedov, E. (2006). Voltage-dependent anion channel (VDAC) as mitochondrial governator-thinking outside the box. Biochim Biophys Acta 1762, 181-190.

Liu, M. Y. \& Colombini, M. (1991). Voltage gating of the mitochondrial outer membrane channel VDAC is regulated by a very conserved protein. Am J Physiol 260, C371-C374.

Liu, M. Y. \& Colombini, M. (1992). Regulation of mitochondrial respiration by controlling the permeability of the outer membrane through the mitochondrial channel, VDAC. Biochim Biophys Acto 1098, 255-260.

López-Lara, I. M. \& Geiger, O. (2001). Novel pathway for phosphatidylcholine biosynthesis in bacteria associated with eukaryotes. J Biotechnol 91, 211-221.

Mannella, C. A. (1992). The 'ins' and 'outs' of mitochondrial membrane channels. Trends Biochem Sci 17, 315-320.

Marjanović, Ž., Uehlein, N., Kaldenhoff, R., Zwiazek, J. J., Weiß, M., Hampp, R. \& Nehls, U. (2005). Aquaporins in poplar: what a difference a symbiont makes! Planta 222, 258-268.

Motta, M. C. (2010). Endosymbiosis in trypanosomatids as a model to study cell evolution. Open Parasitol J 4, 139-147.

Motta, M. C., Soares, M. J. \& De Souza, W. (1991). Freeze-fracture study of endosymbiont-bearing trypanosomatids of the Crithidia genus. Micr Electr Biol Cel 15, 131-144.

Motta, M. C., Monteiro-Leal, L. H., De Souza, W., Almeida, D. F. \& Ferreira, L. C. (1997a). Detection of penicillin-binding proteins in endosymbionts of the trypanosomatid Crithidia deanei. J Eukaryot Microbiol 44, 492-496.

Motta, M. C., Soares, M. J., Attias, M., Morgado, J., Lemos, A. P., Saad-Nehme, J., Meyer-Fernandes, J. R. \& De Souza, W. (1997b). Ultrastructural and biochemical analysis of the relationship of Crithidia deanei with its endosymbiont. Eur J Cell Biol 72, 370-377.

Nikaido, H. (1992). Porins and specific channels of bacterial outer membranes. Mol Microbiol 6, 435-442.

Nikaido, H. (1993). Transport across the bacterial outer membrane. J Bioenerg Biomembr 25, 581-589.

Nikaido, H. (2003). Molecular basis of bacterial outer membrane permeability revisited. Microbiol Mol Biol Rev 67, 593-656.

Nikaido, H. \& Rosenberg, E. Y. (1981). Effect on solute size on diffusion rates through the transmembrane pores of the outer membrane of Escherichia coli. J Gen Physiol 77, 121-135.
Novak, E., Freymuller, H., Da Silva, S. \& da Silveira, J. F. (1988). Protein synthesis in isolated symbionts from the flagellate protozoon Crithidia deanei. J Protozool 35, 375-378.

Palmié-Peixoto, I. V., Rocha, M. R., Urbina, J. A., de Souza, W., Einicker-Lamas, M. \& Motta, M. C. (2006). Effects of sterol biosynthesis inhibitors on endosymbiont-bearing trypanosomatids. FEMS Microbiol Lett 255, 33-42.

Pei, J. \& Grishin, N. V. (2007). PROMALS: towards accurate multiple sequence alignments of distantly related proteins. Bioinformatics 23, 802-808.

Pohorille, A., Schweighofer, K. \& Wilson, M. A. (2005). The origin and early evolution of membrane channels. Astrobiology 5, 1-17.

Pruitt, K. D., Tatusova, T. \& Maglott, D. R. (2007). NCBI reference sequences (RefSeq): a curated non-redundant sequence database of genomes, transcripts and proteins. Nucleic Acids Res 35 (Database issue, ), D61-D65.

Pugsley, A. P. (1993). The complete general secretory pathway in Gram-negative bacteria. Microbiol Rev 57, 50-108.

Rachel, R., Wyschkony, I., Riehl, S. \& Huber, H. (2002). The ultrastructure of Ignicoccus: evidence for a novel outer membrane and for intracellular vesicle budding in an archaeon. Archaea 1, 9-18.

Reumann, S., Maier, E., Benz, R. \& Heldt, H. W. (1996). A specific porin is involved in the malate shuttle of leaf peroxisomes. Biochem Soc Trans 24, 754-757.

Ruiz, N., Kahne, D. \& Silhavy, T. J. (2006). Advances in understanding bacterial outer-membrane biogenesis. Nat Rev Microbiol 4, 57-66.

Saitou, N. \& Nei, M. (1987). The neighbor-joining method: a new method for reconstructing phylogenetic trees. Mol Biol Evol 4, 406425.

Salzman, T. A., Batlle, A. M., Angluster, J. \& de Souza, W. (1985). Heme synthesis in Crithidia deanei: influence of the endosymbiote. Int J Biochem 17, 1343-1347.

Soares, M. J., De Souza, M. F. \& De Souza, W. (1987). Ultrastructural visualization of lipids in trypanosomatids. J Protozool 34, 199-203.

Tamura, K., Nei, M. \& Kumar, S. (2004). Prospects for inferring very large phylogenies by using the neighbor-joining method. Proc Natl Acad Sci U S A 101, 11030-11035.

Tatusov, R. L., Natale, D. A., Garkavtsev, I. V., Tatusova, T. A., Shankavaram, U. T., Rao, B. S., Kiryutin, B., Galperin, M. Y., Fedorova, N. D. \& Koonin, E. V. (2001). The COG database: new developments in phylogenetic classification of proteins from complete genomes. Nucleic Acids Res 29, 22-28.

von Heijne, G. (1990). Protein targeting signals. Curr Opin Cell Biol 2 , 604-608.

Warren, L. G. (1960). Metabolism of Schizotrypanum cruzi Chagas. I. Effect of culture age and substrate concentration on respiratory rate. J Parasitol 46, 529-539.

Zachariae, U., Klühspies, T., De, S., Engelhardt, H. \& Zeth, K. (2006). High resolution crystal structures and molecular dynamics studies reveal substrate binding in the porin Omp32. J Biol Chem 281, 74137420 .

Zeth, K. \& Thein, M. (2010). Porins in prokaryotes and eukaryotes: common themes and variations. Biochem J 431, 13-22.

Zientz, E., Dandekar, T. \& Gross, R. (2004). Metabolic interdependence of obligate intracellular bacteria and their insect hosts. Microbiol Mol Biol Rev 68, 745-770.

Edited by: G. H. Thomas 